erythroblastopenia of childhood are, indeed, an aged population our findings are inconsistent with a steady exponential decay in the activity of enzymes such as hexokinase and suggest that a rapid loss of enzyme from reticulocytes is followed by relatively little further decline in enzyme activity during the remainder of the red cell life span. Pyrimidine-5'-nucleotidase activity, in contrast, seems to be very largely lost in the first few days of red cell life.

\section{REFERENCES}

1. Labotka RJ, Maurer HS, Honig GR 1981 Transient erythroblastopenia of childhood. Am J Dis Child 135:937-940

2. Beutler E 1975 Red Cell Metabolism. A Manual of Biochemical Methods, 2nd ed. Grune \& Stratton, New York

3. Torrance J, West C, Beutler E 1977 A simple rapid radiometric assay for pyrimidine-5'-nucleotidase. J Lab Clin Med 90:563-568

4. Beutler E 1983 Detection of pyrimidine nucleotides. In: Williams WJ, Beutler E, Erslev AJ, Lichtman MA (ed) Hematology, 3rd ed. McGraw-Hill, Inc., New York, p 1644

5. Valentine WN, Fink K, Paglia DE, Harris SR, Adams WS 1974 Hereditary hemolytic anemia with human erythrocyte pyrimidine 5'-nucleotidase deficieny. J Clin Invest 54:866-879
6. Beutler E, Baranko PV, Feagler J, Matsumoto F, Miro-Quesada M, Selby G, Singh P 1980 Hemolytic anemia due to pyrimidine-5'-nucleotidase deficiency: Report of eight cases in six families. Blood 56:251-255

7. Wang WC, Mentzer WC 1976 Differentiation of transient erythroblastopenia of childhood from congenital hypoplastic anemia. J Pediatr 88:784-789

8. Löhr GW, Waller HD 1959 Zellstoffwechsel und zellalterung. Klin Wochenschr 37:833-843

9. Piomelli S, Corash LM, Davenport DD, Miraglia J, Amorosi EL 1968 In vivo lability of glucose-6-phosphate dehydrogenase in GdA- and GD-Mediterranean deficiency. J Clin Invest 47:940-948

10. Turner BM, Fisher RA, Harris $H 1974$ The age related loss of activity of four enzymes in the human erythrocyte. Clin Chim Acta 50:85-95

11. Syllm-Rapoport I, Daniel A, Starck H, Hartwig A, Gross J 1981 Creatine in density-fractionated red cells, a useful indicator of erythropoietic dynamics and of hypoxia past and present. Acta Haematol 66:86-95

12. Bartos HR, Desforges JF 1967 Enzymes as erythrocyte age reference standards. Am J Med Sci 254:862-865

13. Seaman C, Wyss S, Piomelli S 1980 The decline in energetic metabolism with aging of the erythrocyte and its relationship to cell death. Am J Hematol 3:31-42

14. Muller M, Dubiel W, Rathmann J, Rapoport S 1980 Determination and characteristics of energy-dependent proteolysis in rabbit reticulocytes. Eur $\mathbf{J}$ Biochem 109:405-410

15. Beutler E 1985 Biphasic loss of red cell enzyme activity during in vivo aging. In: Eaton JW, White JG (ed) Cellular and Molecular Aspects of Aging: The Red Cell as a Model. Alan R. Liss, Inc., New York, NY

\title{
Plasma and Urinary Catecholamines in Patients with Cystic Fibrosis
}

\author{
MARTIN H. SCHÖNI, KURT TÜRLER, HANS KÄSER, AND RICHARD KRAEMER \\ Institute for Clinical and Experimental Cancer Research [M.H.S., K.T., H.K.] and Department of Pediatrics
}

[R.K.], University of Berne, Switzerland

\begin{abstract}
In 43 patients with cystic fibrosis (age 8-23 yr, 26 boys and 17 girls) attending a summer camp in a mountain rehabilitation center and in 25 parents (heterozygotes) plasma epinephrine, norepinephrine, dopamine and plasma activity of dopamine- $\beta$-hydroxylase were determined as well as the 24-h excretion of the free urinary amines (epinephrine, norepinephrine, dopamine), their $O$ methylated products (metanephrine, normetanephrine, 3methoxytyramine) and the urinary phenolic acids (vanilmandelic and homovanillic). Also the metabolic breakdown product of serotonin in urine, the 5-hydroxyindoleacetic acid, was determined. Significantly elevated plasma dopamine (0.03-0.45 nmol/liter for controls versus 1.70-2.21 nmol/liter for cystic fibrosis) and slightly higher plasma norepinephrine levels were found in patients with cystic fibrosis. An increased 5-hydroxyindoleacetic acid excretion was noticed in adolescent patients which correlated with the disease state and the extent of lung involvement. No abnormalities of plasma amine levels were seen in the parents of the patients. Despite controversial results, CF patients seem to have an alteration in catecholamine me-
\end{abstract}

Received March 15, 1984, accepted July 24, 1984.

Reprint address R. Kraemer, M.D., Department of Pediatrics, University of Berne, Inselspital, $\mathrm{CH}-3010$ Berne, Switzerland.

The study was supported in part by the Swiss National Foundation for Scientific Research. M. H. Schöni is a recipient of a Research Grant from the same institution to conduct cystic fibrosis research in Vancouver, Canada. tabolism which is reflected in higher plasma dopamine levels. (Pediatr Res 19: 47-52, 1985)

\section{Abbreviations}

CF, cystic fibrosis

$\mathrm{HZ}$, heterozygotes

E, epinephrine

NE, norepinephrine

DA, Dopamine

DBH, dopamine- $\beta$-hydroxylase

DOPA, 3,4-dihydroxyphenylalanine

DOPAC, 3,4-dihydroxyphenylacetic acid

MN, metanephrine

NM, normetanephrine

3-MT, 3-Methoxytyramine

VMA, vanilmandelic acid

HVA, homovanillic acid

5-HIAA, 5-hydroxyindoleacetic acid

COMT, catechol- $O$-methyltransferase

MAO, monoaminooxidase

Two earlier reports described elevated free urinary catecholamines (2) and adrenal medullary hyperplasia (3) in patients 
with CF. From these observations it was suggested that elevated levels of circulating catecholamines might be responsible for an autonomic dysfunction in $\mathrm{CF}$. Other studies indicated that $\mathrm{CF}$ patients have increased cholinergic and $\alpha_{1}$-adrenergic sensitivity in conjunction with reduced $\beta_{2}$-adrenergic responses (12). This assumption was drawn from observations in patients who showed altered pupillary reactivity to physical and chemical stimuli (29), relative insensitivity of blood pressure to beta adrenergic bronchodilatation $(9,18)$ or altered in vitro results from several $\mathrm{CF}$ derived cell preparations (fibroblasts, blood cells, tissue explants) $(7,27,32)$. In contrast, Lake et al. (17) reported normal plasma norepinephrine levels and normal activity of $\mathrm{DBH}$ in $\mathrm{CF}$ patients. It was speculated, therefore, that neither synthesis nor degradation of catecholamines was affected in CF and, that the observed autonomic dysfunction might not be due to circulating biogenic amines.

In view of these conflicting results, the present study was designed to elucidate whether circulating plasma catecholamines, their precursors, metabolites and major urinary products are altered in CF patients and heterozygotes, An attempt was made to correlate these findings to the state of the disease, different blood variables, blood pressure, and heart rate as well as to the sweat electrolyte abnormality.

\section{MATERIALS AND METHODS}

Patients and controls. Blood and 24-h urine samples were collected from 43 children and adolescents with CF ( 26 boys and 17 girls, range 8-23 yr) attending a summer camp for intensive physiotherapy treatment in a mountain rehabilitation center. All children were treated with the same drug, pancrease (Prolipase), for supplementation of pancreatic insufficiency, all had the same daily meals and equal daily inhalation therapy with a $\beta_{2}$-sympathomimetic drug (hexoprenaline-sulfate, Ipradol). Thirty-five patients received antibiotics orally; no intravenous or further drug therapy was used. All children attended the same physical training and physiotherapy regimen. All children and parents gave informed consent to participate in the study.

In 25 parents a single blood specimen could be obtained at the time of admission of the children to the rehabilitation center. Eight healthy adults without a family history of CF served as controls and were investigated at the same time. Values from normal healthy children, collected over several years and measured in the laboratory, performing daily routine catecholamine determinations were randomly selected as age matched and used as controls.

Clinical investigation and laboratory methods. Clinical state, weight, height, blood pressure, and heart rate were evaluated at the admission to the clinic. Chest radiographic scores were determined by the Chrispin Norman scoring system (5). Each child had a sweat test on the day of blood sampling performed by the Webster Sweat Stimulation/Collection system with osmolality determinations (30). Blood gas analysis (ear oxymetry) and determinations of total protein, electrolytes, creatinine, SGOT, SGPT, plasma osmolality, copper, and ceruloplasmin were done by routine laboratory methods.

Collection of samples. In the CF patients, after an 8-h or more overnight rest, blood samples were collected by acute needle stick from the cubital vein with heparin and placed immediately on ice. By the same procedure blood was drawn from the parents after a short rest in supine position. The eight controls were treated accordingly. The plasma was quickly separated by centrifugation, decanted, and frozen, All samples were stored at $-20^{\circ} \mathrm{C}$ until used (determinations done within 10 days; experiments performed on days 1 and 10 showed no activity change during that storing period).

Determination of catecholamines and their metabolites in urine. The extraction of the catecholamine acids was done using Clin Elute extraction columns (Analytichem International, Inc, Harbor City, CA). VMA, HVA, and 5-HIAA were determined by high pressure liquid chromatography with electrochemical detection as described by Kissinger et al. (15) and Mattiuz et al. (20). The system contained a Kontron Analytic Programmer 200 , a Kontron Analytic pump 410, an injection value Rheodyne 7125, a $5 \mu$ Ultrasphere Biophase ODS column, $4.6 \times 250 \mathrm{~mm}$ (Beckman Instruments), and a LC 3 amperometric detector with a LC 17 oxidative flow cell containing a glassy carbon working electrode (Bioanalytical Systems, Inc, West Lafayette, IN); the mobil phase was $0.15 \mathrm{M}$ monochloroacetate buffer, $\mathrm{pH} 3.0$ containing $2 \mathrm{~mm} \mathrm{Na} \mathrm{NaDTA}_{2}$ and $300 \mathrm{mg} /$ liter sodium octyl sulfate with $8 \%$ acetonitrile. The flow rate was $1.5 \mathrm{ml} / \mathrm{min}$ at a temperature of $28^{\circ} \mathrm{C}$ and the amount injected was $10 \mu \mathrm{l}$. Peak heights were determined by a Spectra Physics Mod 4100 electronic integrator.

Free E, NE, DA and MN, NM, 3-MT were isolated from the urine by the ion exchange procedure of Carlson and Waldeck (4). The catecholamines and their metabolites were assayed fluorimetrically by the method of Käser (14). All values were expressed in $\mu \mathrm{mol}$ or $\mathrm{nmol} / 24 \mathrm{~h}$ or in $\mathrm{nmol} / \mu \mathrm{mol}$ of urinary creatinine, measured by a modified Jaffe reaction (22).

Determinations of plasma catecholamines and of $\mathrm{DBH}$. Simultaneous radioenzymatic determinations of $\mathrm{E}, \mathrm{NE}$, and DA were done according to the method of Passon and Peuler (24), Peuler and Johnson (25), and Da Prada and Zürcher (6) using COMT from pig liver, prepared by the method of Axelrod and Tomchick (1). The photometric assay of Nagatsu and Udenfriend (21) was used for the determinations of plasma DBH.

Statistics. Since many of the determined variables are age dependent we devided controls and patients randomly into three groups: age group 5-9 yr ( $n$ for $C F=5)$, age group 10-14 yr $(n$ $=19)$, and age group 15-19 $\mathrm{yr}(n=19)$. In the latter group, two patients older than $19 \mathrm{yr}(21$ and $23 \mathrm{yr})$ were included. In our hands, this age grouping proved to be accurate to evaluate patients with neuroblastoma and/or pheochromocytoma due to elevated plasma and urinary catecholamines (14). Statistical analysis was performed by the nonparametric Wilcoxon-MannWhitney test and the Spearman rank correlation.

\section{RESULTS}

Table 1 shows some of the anthropometric and serum data of the CF patients. The values for electrolytes, creatinine clearance, blood pressure, and heart rate were not statistically significant different from normal values for age. However, 10 children had slightly elevated transaminases, one in the youngest age group, six in the middle, and three in the oldest age group. The mean copper concentration in the plasma of all patients was $22.5 \pm$ $3.6 \mu \mathrm{mol} /$ liter (mean $\pm \mathrm{SD}$ ) with a corresponding caeruloplasmin concentration of $0.23 \pm 0.02 \mathrm{~g} /$ liter. Therefore, as compared to normal values, nine $\mathrm{CF}$ had patients slightly elevated plasma copper and caeruloplasmin concentrations.

Sweat osmolality was elevated in all 43 children, showing a mean value of $264 \pm 20 \mathrm{mmol} / \mathrm{kg}$ (mean $\pm \mathrm{SD}$ ) ranging from 190-302 mmol/kg, values which are diagnostic for CF (30).

The 24-h urine production of CF patients was slightly, but not significantly higher than that of control children (not shown). No differences in the urine creatinine concentrations between $\mathrm{CF}$ and normals were present.

As shown in Figure 1 the VMA and HVA excretion over $24 \mathrm{~h}$ and the concentration per $\mu$ mol urinary creatinine were age dependent and showed no difference between patients and controls. Furthermore, the free urinary E, NE, and DA (results not shown) were normal in $\mathrm{CF}$ as were the total $O$-methylated products, MN, NM, and 3-MT. Figure 2 shows the results of the urinary excretion of 5-HIAA. An age-dependent increase which resulted in a significantly higher excretion of 5-HIAA for the oldest age group was found.

Table 2 gives the median and range values for free plasma, $\mathrm{E}$, NE, DA, and DBH. Compared to controls, significantly elevated values of free plasma dopamine were present in the $C F$ patients 
Table 1. Anthropometry and serum data of CF patients according to age (median and range)

\begin{tabular}{|c|c|c|c|}
\hline Age $(\mathrm{yr})$ & $5-9$ & $10-14$ & $15-19$ \\
\hline $\mathrm{Wt}(\mathrm{kg})$ & $\begin{array}{c}22.5 \\
20.3-30.3\end{array}$ & $\begin{array}{c}29.7 \\
16.3-42.5\end{array}$ & $\begin{array}{c}45.5 \\
33.5-60.6\end{array}$ \\
\hline Norman score (points) & $\begin{array}{l}12 \\
5-13\end{array}$ & $\begin{array}{l}12 \\
7-19\end{array}$ & $\begin{array}{l}16 \\
10-25\end{array}$ \\
\hline Heart rate & $\begin{array}{l}88 \\
84-110\end{array}$ & $\begin{array}{l}84 \\
64-116\end{array}$ & $\begin{array}{l}80 \\
64-96\end{array}$ \\
\hline $\begin{array}{l}\text { Systolic blood pressure } \\
(\mathrm{mm} \mathrm{Hg})\end{array}$ & $\begin{array}{l}100 \\
90-106\end{array}$ & $\begin{array}{l}110 \\
90-125\end{array}$ & $\begin{array}{l}120 \\
105-125\end{array}$ \\
\hline $\mathrm{po}_{2}(\mathrm{~mm} \mathrm{Hg})$ & $\begin{array}{c}75.4 \\
62.8-83.0\end{array}$ & $\begin{array}{c}76.0 \\
50.3-84.3\end{array}$ & $\begin{array}{c}67.9 \\
59.2-86.2\end{array}$ \\
\hline $\mathrm{pCO}_{2}(\mathrm{~mm} \mathrm{Hg})$ & $\begin{array}{c}35.5 \\
34.9-37.4\end{array}$ & $\begin{array}{c}35.5 \\
33.4-42.4\end{array}$ & $\begin{array}{c}36.5 \\
27.5-44.0\end{array}$ \\
\hline $\begin{array}{r}\text { Creatinine clearance } \\
\left(\mathrm{ml} / \mathrm{min} / 1.73 \mathrm{~m}^{2}\right)\end{array}$ & $\begin{array}{l}92.9 \\
45-140\end{array}$ & $\begin{array}{l}104.2 \\
46-198\end{array}$ & $\begin{array}{l}110.6 \\
46-207\end{array}$ \\
\hline $\begin{array}{l}\text { Serum osmolality } \\
\text { (mmol/liter) }\end{array}$ & $\begin{array}{c}281.6 \\
279-283\end{array}$ & $\begin{array}{c}285.2 \\
275-291\end{array}$ & $\begin{array}{l}286.8 \\
280-301\end{array}$ \\
\hline $\begin{array}{l}\text { Serum chloride } \\
(\mathrm{mmol} / \mathrm{liter})\end{array}$ & $\begin{array}{l}102 \\
101-104\end{array}$ & $\begin{array}{l}102 \\
99-109\end{array}$ & $\begin{array}{l}103 \\
95-114\end{array}$ \\
\hline $\begin{array}{l}\text { Serum potassium } \\
(\mathrm{mmol} / \text { liter })\end{array}$ & $\begin{array}{c}4.5 \\
4.25-4.80\end{array}$ & $\begin{array}{c}4.7 \\
4.10-5.50\end{array}$ & $\begin{array}{c}4.6 \\
4.00-5.30\end{array}$ \\
\hline $\begin{array}{l}\text { Serum calcium } \\
(\mathrm{mmol} / \mathrm{liter})\end{array}$ & $\begin{array}{r}2.46 \\
2.3-2.8\end{array}$ & $\begin{array}{r}2.39 \\
2.2-2.6\end{array}$ & $\begin{array}{r}2.37 \\
2.2-2.6\end{array}$ \\
\hline $\begin{array}{l}\text { Serum bicarbonate } \\
(\mathrm{mmol} / \mathrm{liter})\end{array}$ & $\begin{array}{c}22.5 \\
21.7-23.1\end{array}$ & $\begin{array}{c}22.2 \\
18.9-25.9\end{array}$ & $\begin{array}{c}22.6 \\
17.8-26.6\end{array}$ \\
\hline $\begin{array}{r}\text { Serum sodium } \\
(\mathrm{mmol} / \mathrm{liter})\end{array}$ & $\begin{array}{c}139 \\
136-141\end{array}$ & $\begin{array}{l}140 \\
137-145\end{array}$ & $\begin{array}{l}139 \\
131-147\end{array}$ \\
\hline
\end{tabular}

( $p<0.001$ for all age groups). Only in two CF children, plasma DA was found to be in the upper normal range for age. The elevated levels did not correlate with the Chrispin Norman scores, weight, blood pressure, or with any other determined variable. Interestingly, no significant linear correlation of urinary DA to plasma DA levels could be demonstrated $(r=0.347)$. Also the final breakdown product of DA in urine, the HVA, was not correlated to the plasma DA levels. Plasma DA levels were neither related to the nutrient intake nor to the type and dose of drugs used. Obviously, the age-dependent plasma DA decrease observed in controls could not be found in CF. No abnormalities in plasma levels of $E, N E$, and DA (E: 0.076-0.604; NE: $0.91-$ 3.84; DA: 0.08-1.48; indicated are ranges in $\mathrm{nmol} / \mathrm{liter}$ ) could be demonstrated in the parents of patients when compared to the adult controls.

DBH activity varied greatly in controls, parents, and patients: no differences or correlations could be established. Since this enzyme contains copper we attempted to relate its activity to plasma copper concentrations and to copper-binding protein. No dependence was obvious and there was no link between the parent's DBH activity and that found in their children.

\section{DISCUSSION}

This study shows normal excretion of the phenolic acids (VMA, HVA) in CF patients. Furthermore, the free urinary amines, E, NE, and DA as well as their $O$-methylated products $\mathrm{MN}, \mathrm{NM}$, and 3-MT were within the normal range for age. In addition, an age-dependent increase of the 5-HIAA excretion in urine was noticed. On the other hand, in plasma, besides normal $\mathrm{E}$ and normal DBH, significantly elevated DA concentrations and slightly higher NE values were detected in the CF patients. As shown in Figure 3, E, NE, and DA are synthesized via DOPA form the amino acid tyrosine. The metabolism of these catecholamines is regulated mainly by a few elementary types of enzymatically catalyzed reactions, i.e. hydroxylation, methyation, acetylation, oxodative deamination, and conjugation to sulfate or glucuronide (10). Each metabolic product tends to
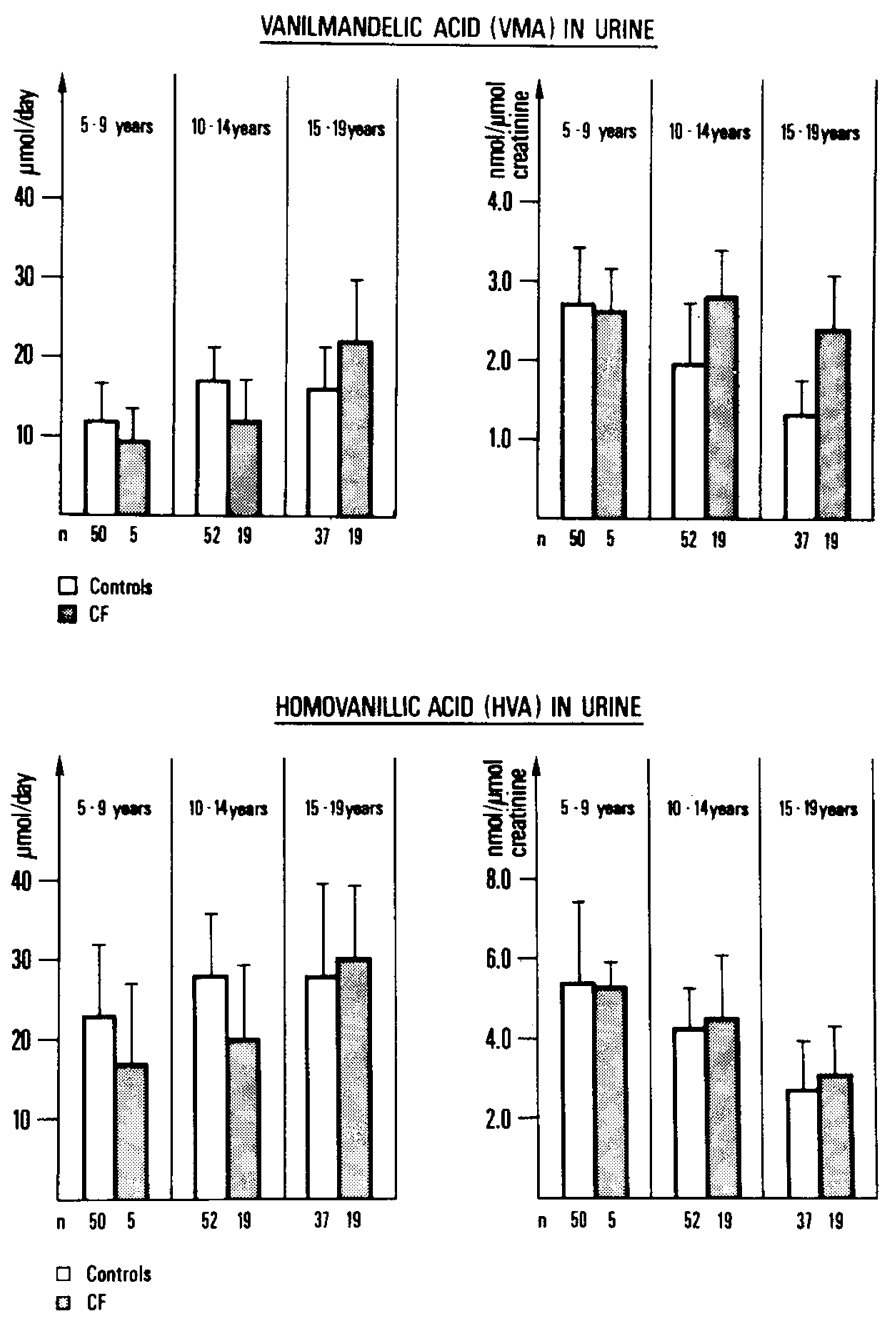

Fig. 1. Urinary excretion of the two phenolic acids, VMA and HVA. The mean $\pm \mathrm{SD}$ is indicated.

traverse one main synthetic or catabolic pathway leading to numerous substances, which in turn can be stored, further metabolized, or excreted. It is generally accepted that the main breakdown product of dopamine is HVA, and of epinephrine/ norepinephrine, VMA. The determination of these phenolic acids in urine therefore provides some insight into the function of the sympathoadrenal system.

The finding of elevated free urinary catecholamines in CF has been cited by several authors $(8,9,29)$. However, these results have never been reproduced by modern laboratory techniques. For several years therefore the possibility of a disturbed autonomic regulation in $\mathrm{CF}$ has been suggested (19). Our results indicating normal urinary VMA and HVA argue against a main alteration in the peripheral sympathetic autonomic regulation. This conclusion can be underlined by the fact that normal excretion of free $\mathrm{E}, \mathrm{NE}$, and $\mathrm{DA}$ and of their $O$-methylated products was observed. Further evidence for this assumption is provided by the normal plasma $\mathrm{DBH}$ activity confirming the findings of Lake et al. (17).

However, the striking feature of our study is the significantly elevated plasma dopamine concentration contrasted with the normal urinary dopamine and normal HVA. The most important metabolic pathway for dopamine is its hydroxylation to NE, a reaction catalyzed by $\mathrm{DBH}$. On the other hand, dopamine can be deaminated oxodatively to DOPAC by MAO or $O$-methylated to 3-MT by COMT; from these two resulting compounds homovanillic acid is derived. A further important possibility of inactivation is either a reuptake of DA into nerve endings or its 


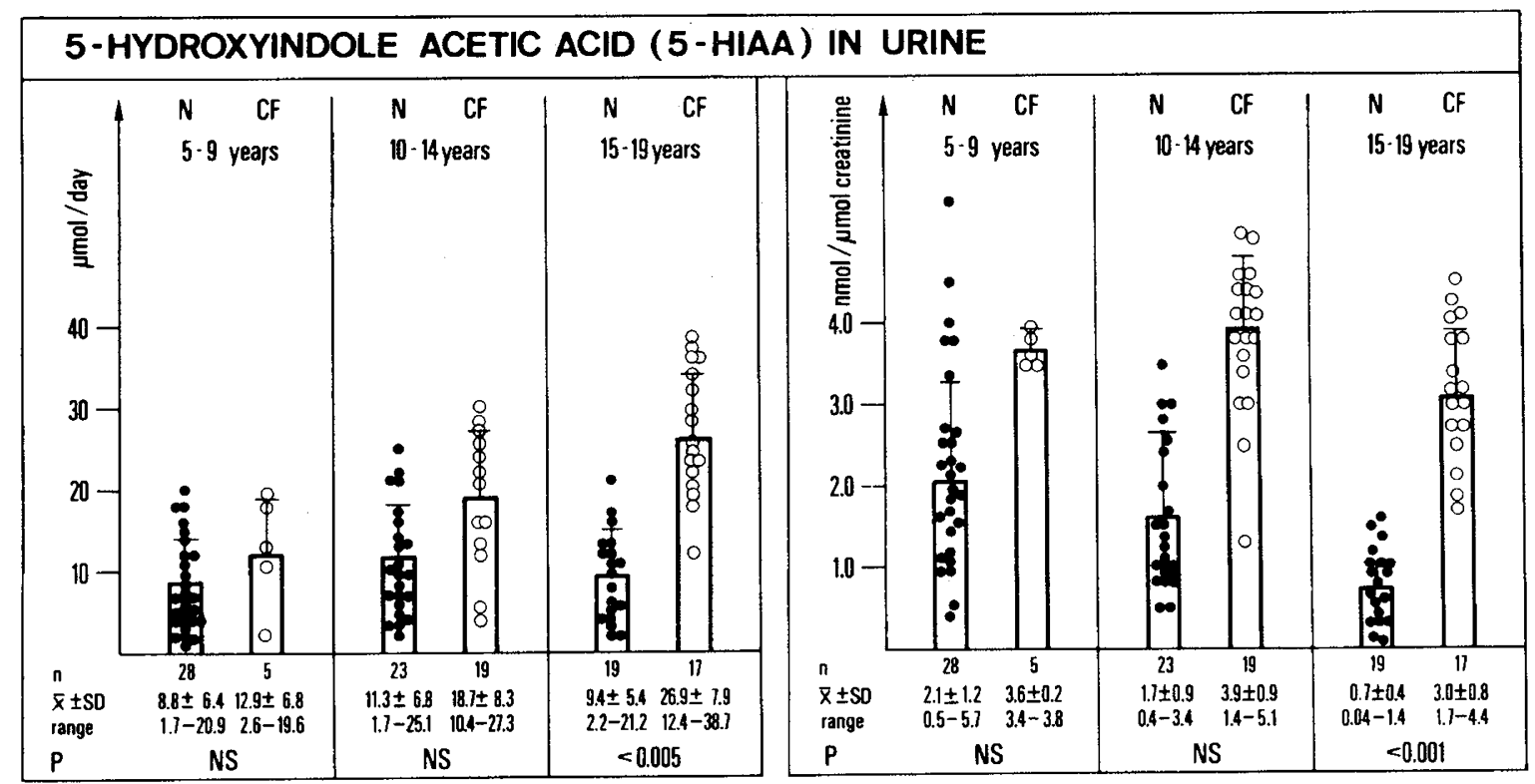

Fig. 2. Excretion of 5-HIAA in urine according to age. Single values and mean \pm SD are indicated.

Table 2. Plasma concentrations of $E, N E, D A$, and $D B H$ activity according to age

\begin{tabular}{|c|c|c|c|c|c|c|c|c|c|c|c|c|}
\hline \multirow{2}{*}{$\begin{array}{l}\text { Age } \\
(\mathrm{yr})\end{array}$} & \multicolumn{3}{|c|}{ Normal } & \multicolumn{3}{|c|}{$\mathrm{CF}$} & \multicolumn{3}{|c|}{ Normal } & \multicolumn{3}{|c|}{$\mathrm{CF}$} \\
\hline & $n$ & Median & Range & $n$ & Median & Range & $n$ & Median & Range & $n$ & Median & Range \\
\hline
\end{tabular}

E (nmol/liter)

\begin{tabular}{ccccc}
$5-9$ & $(15)$ & 0.453 & $0.098-0.699$ & $(5)$ \\
$10-14$ & $(34)$ & 0.300 & $0.076-0.655$ & $(19)$ \\
$15-19$ & $(10)$ & 0.126 & $0.082-0.469$ & $(19)$ \\
& & & \multicolumn{3}{c}{ DA (nmol/liter) }
\end{tabular}

$$
5-9
$$

$$
\text { (11) }
$$

0.457

$10-14$

(23)

(10) 0.039

$\begin{array}{rrr}0.010-0.849 & (5) & 1.70 \\ 0.007-0.986 & (19) & 3.44 \\ 0.010-0.202 & (19) & 2.21\end{array}$

0.303

0.403

0.291 $\begin{array}{ll}0.085-0.881 & (16) \\ 0.118-1.900 & (33) \\ 0.010-0.631 & (10)\end{array}$
$\mathrm{NE}$ (nmol/liter)

$\begin{array}{rrrrrl}(16) & 1.67 & 0.63-3.10 & (5) & 2.53 & 2.22-4.27 \\ (33) & 1.66 & 0.55-3.26 & (19) & 4.06 & 1.18-6.02^{*} \\ (10) & 1.91 & 0.65-2.75 & (19) & 2.78 & 0.07-5.00\end{array}$

${ }^{*} p<0.001$ for normals and CF.

$\mathrm{DBH}(\mu \mathrm{mol} / \mathrm{liter} / \mathrm{min})$

conjugation to sulfate or glucuronide (16). It appears from several recent reports that the formation of the sulfoconjugate is the preferential pathway for the inactivation and excretion of DA, as well as for other catecholamines. Since the free urinary catecholamines $\mathrm{E}, \mathrm{NE}$, and DA were normally excreted by the CF patients we also determined the sulfoconjugated compound in eight children. No alterations were found and it seems that no sulfoconjugation defect for these catecholamines in $\mathrm{CF}$ is present.

Our results of the plasma control NE levels are in agreement with those values published by Lake et al. (17). However, our $\mathrm{NE}$ concentrations of age comparable CF patients are about 2 fold higher. This discrepancy might be based on different $\mathrm{CF}$ patients investigated; our patients in the oldest age group had a severer degree of disease than those reported by Lake et al. (17), who were in good to excellent condition. Despite the absence of a direct correlation of disease severity with our plasma catecholamine levels, we believe that chronic hypoxia influenced basal NE levels. Whether an appropriate catecholamine response to an acute hypoxic stimulus occurs in $\mathrm{CF}$ patients or whether chronic hypoxia turns down the physiological regulation remain to be determined. It is not surprising that in an heterogenous group of $\mathrm{CF}$ patients with different lung involvement and fluctuating capillary $\mathrm{pO}_{2}$ and $\mathrm{pCO}_{2}$ tension (due to the presence of different degree of lung infection or simply due to different temporarely effective or ineffective physiotherapy) no direct correlations of plasma catecholamine levels and disease severity could be established.

It has been shown during pubescence that the chronological age of CF patients might not reflect the physiologic age; therefore our age grouping might be inadequate. In fact, this could have influenced our NE values for the middle age group which actually revealed somewhat elevated levels. However, this would not explain the overall elevation for the dopamine in all age groups.

Whether blood sampling techniques alter endogenous catecholamine levels is not clear, and reports in children are not available. According to Robertson et al. (26) direct venepuncture versus heparin-lock sampling did not affect mean plasma $\mathrm{E}, \mathrm{NE}$, and DA levels. We also believe that in children an acute venepuncture by a small needle is a much milder and less traumatic procedure than the insertion of an indwelling catheter which must be held in position and heparin locked. In our hands heparin-locked catheters generated problems in smaller children and in patients with higher hematocrits because of catheter pluging. The manipulation required to sample blood after such an event generate more stress in children than a quickly done acute venepuncture. Furthermore ethical reasons of performing such manipulations must be taken into consideration. It seems very unlikely that our technique increased the DA levels in the 
PHENYLALANINE

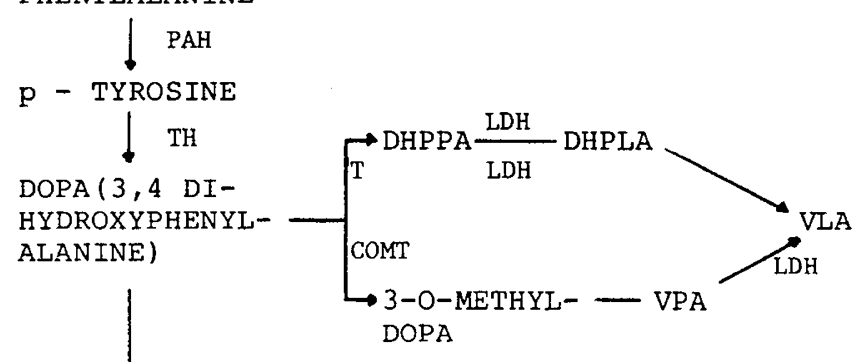

$\mathrm{DC}$
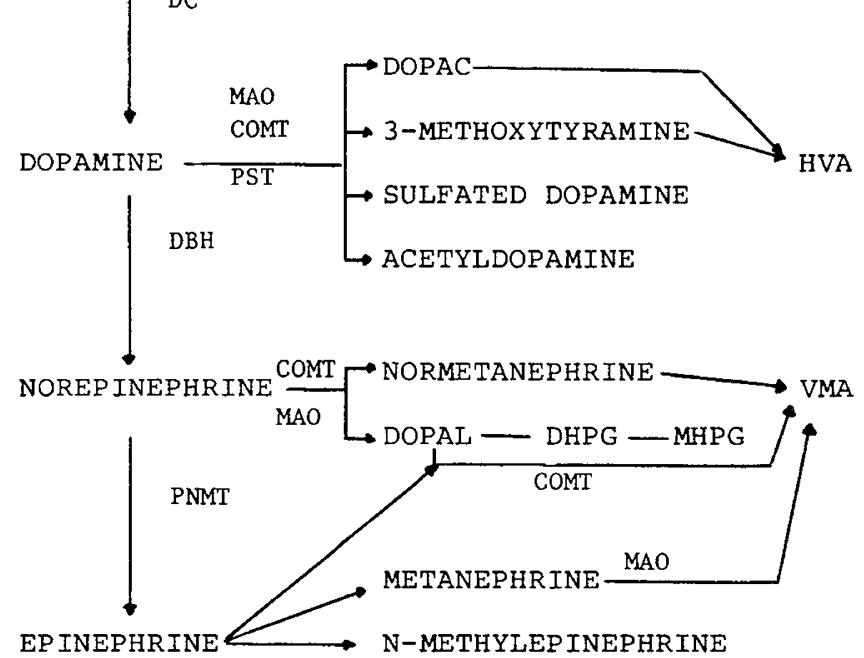

Fig. 3. PNMT, phenylethanolamine-N-methyltransferase; PAH, phenylalanine hydroxylase; TH, tyrosine hydroxylase; PST, phenylsulfotransferase; $\mathrm{LDH}$, lactate-dehydrogenase; $\mathrm{T}$, transaminase.

reported amounts with no concommitant elevation of $\mathrm{NE}$ and E.

The significance of the combination of findings in our CF patients, elevated plasma DA, slightly elevated plasma NE, normal urinary DA, NE, and HVA, remains obscure. The elevated 5 -HIAA excretion is in contrast to the results published by Partington and Ferguson (23). This difference may derive either from the method used for the determination of 5-HIAA in urine or patient selection. As demonstrated by our results, only the older patients had an increased 5-HIAA loss. This increase in CF contrasts to the fairly stable, age-dependent daily 5-HIAA excretion in the controls. Whereas the concentration of the 5-HIAA/ $\mu$ mol creatinine normally decreased with age, the concentration in $\mathrm{CF}$ remained unchanged. Since the creatinine loss in CF patients and controls was equal, the significant difference between controls and CF of the oldest age group cannot be explained on the basis of age-dependent urinary creatinine output.

It has been known since the report of Gaddum et al. (11) that blood serotonin is removed in part by the lung. Under normal conditions, serotonin is rapidly taken up by the pulmonary endothelial cells of both large vessels and capillaries by a sodiumdependent carrier-mediated transport mechanism and is oxydized into 5-HIAA (31). Furthermore, evidence suggests that some accumulation of serotonin and 5-HIAA might occur in the bronchi (13). From these observations it can be assumed that impaired lung function might contribute to increased blood serotonin and consequently to increased 5-HIAA output in CF. This would explain our observation of a pathological 5-HIAA excretion increasing with age and pulmonary involvement. Although we did not perform pulmonary function tests, a correlation with lung involvement, as determined by the Norman scores and the capillary $\mathrm{O}_{2}$ tension, was found $(\mathrm{r}=0.780)$. Since Partington and Ferguson (23) ruled out the interference of therapy and nutrition in their reports of raised blood serotonin in
$\mathrm{CF}$ we suggest that the degree of the pulmonary involvement might contribute to the elevated 5-HIAA in urine.

Our results demonstrate that alterations in the metabolism of biogenic amines and seortonin in CF are present. Further work is therefore needed to substantiate its significance to the basic defect in $\mathrm{CF}$.

Acknowledgments. The authors gratefully acknowledge the help of the laboratories of Dr. E. Peheim, M.D., Central Labortory of the University Clinic, Inselspital Berne, Dr. F. Mühlberger, M.D., Bernese Mountain Clinic in Montana, Wallis, MT and the laboratory staff in the Metabolic Unit, Institute for Clinical and Experimental Cancer Research, University of Berne, Switzerland. The determinations of the urinary sulfoconjugates were kindly performed by Dr. G. Zürcher, Ph.D., in the laboratory of Professor M. Da Prada, M.D., Hoffmann LaRoche, Basle, Switzerland.

\section{REFERENCES}

1. Axelrod J, Tomchick R 1958 Enzymatic $O$-methylation of epinephrine and other catechols. J Biol Chem 233:702

2. Barbero GJ, Braddock LI 1967 Catecholamines in cystic fibrosis. Lancet 2:158

3. Bongiovanni AM, Yakovac WC, Steiker DD 1961 Study of adrenal glands in childhood: hormonal content correlated with morphologic characteristics. Lab Invest 10:956

4. Carlsson A, Waldeck B 1958 Fluorimetric method for determination of dopamine (3-hydroxytyramine). Acta Physiol Scand 44:293

5. Chrispin, AR, Norman AP 1974 The systematic evaluation of the chest radiograph in cystic fibrosis. Pediatr Radiol 2:101

6. Da Prada M, Zürcher G 1976 Simultaneous radioenzymatic determination of plasma and tissue adrenaline, noradrenaline and dopamine within the femtomole range. Life Sci 19:1161

7. Davis PB, Dieckman L, Boat TF, Stern RC, Doershuk CF 1983 Beta adrenergic receptors in lymphocytes and granulocytes from patients with cystic fibrosis. $\mathrm{J}$ Clin Invest 71:1787

8. Davis PB, Kaliner M 1983 Autonomic nervous system abnormalities in cystic fibrosis. J Chronic Dis 36:269

9. Davis PB, Shelhamer JR, Kaliner M 1980 Abnormal adrenergic and cholinergic sensitivity in cystic fibrosis. N Engl J Med 302:1453

10. Franzen F, Eysell K 1969 Biologically active amines found in man, 1st ed. Pergamon Press, London, pp 2-62

11. Gaddum JH, Hebb CO, Silver A, Swan AAB 1953 5-Hydroxytryptamine: pharmacological action and destruction in perfused lungs. Q J Exp Physiol $38: 255$

12. Galant SP, Norton L, Wood C 1981 Impaired beta adrenergic receptor binding and function in cystic fibrosis neutrophils. J Clin Invest 68:253

13. Gershon MD, Ross LL 1966 Location of sites of 5-hydroxytryptamine storage and metabolism by radioautography. J Physiol (Lond) 186:477

14. Käser H 1972 Biochemische Diagnostik des Phäochromocytoms, des Neuroblastoms und anderer neuro-ektodermaler Neoplasien. Helv Paediatr Acta (suppl 29):71-77

15. Kissinger PT, Craig S, Shoup B, Shoup RE 1972 Neurochemical applications of liquid chromatography with electrochemical detection. Life Sci 28:455

16. Kuchel O, Buu NT, Serri O 1982 Sulfoconjugation of catécholamines, nutrition and hypertension. Hypertension 4(suppl III):III-93

17. Lake CR, Davis PB, Ziegler M, Kopin IJ 1979 Electrolytes and norepinephrine levels in blood of patients with cystic fibrosis. Clin Chim Acta 92: 141

18. Larsen GL, Borron RJ, Cotten EK, Brooks JG 1979 Comparative study of inhaled atropine sulfate and isoproterenol hydrochloride in cystic fibrosis. Am Rev Respir Dis 119:399

19. Mangos JA, Bargman GJ, Martinez JR, Rennert OM 1976 Physiology and pharmacology of secretion and cystic fibrosis. In: Mangos JA, Talamo RC (eds) Cystic Fibrosis-Projection into the Future. Stratton Intercont. Med. Book Corp., New York, pp 311-336

20. Mattiuz EL, Webb JW, Gates SC 1982 High resolution separation of urinary organic acids by high performance liquid chromatography. J Liquid Chromatogr 5:2343

21. Nagatsu T, Udenfriend S 1972 Photometric assay of dopamine-beta-hydroxylase activity in human blood. Clin Chem 18:980

22. Owen JA, Iggo B, Scandrett FJ, Stewart CP 1954 The determination of creatinine in plasma or serum and in urine; a critical examination. Biochem J 58:426

23. Partington MW, Ferguson AC 1977 Serotonin metabolism in cystic fibrosis. Arch Dis Child 52:386

24. Passon PG, Peuler JD 1973 A simplified radiometric assay for plasma norepinephrine and epinephrine. Anal Biochem 51:618

25. Peuler JD, Johnson GA 1977 Simultaneous single isotope radioenzymatic assay of plasma norepinephrine, epinephrine and dopamine. Life Sci 21:625

26. Robertson D, Johnson GA, Robertson RM, Nies AS, Shand DG, Oates JA 1979 Comparative assessment of stimuli that release neuronal and adrenomedullary catecholamines in man. Circulation 59:637 
27. Roscher AA, Schmid AJ, Hadorn B, Wiesmann UN 1980 Enhanced adenosine $3^{\prime}: 5^{\prime}$-monophosphate response to beta-adrenergic stimulation in cystic fibrosis fibroblasts after removal of conditioned medium. Pediatr Res 14:261

28. Roth JA, Rivett AJ 1982 Does sulfate conjugation contribute to the metabolic inactivation of catecholamines in humans? Biochem Pharmacol 31:3017

29. Rubin LS, Barabero GJ, Chernick WS 1966 Pupillary dysfunction as a concomitant of cystic fibrosis. Pediatrics 38:865

30. Schöni MH, Kraemer R, Bähler P, Rossi E 1984 Early diagnosis of cystic fibrosis by means of sweat microosmometry. J Pediatr 104:691

31. Strum J, Junod AF 1972 Autoradiographic demonstration of ${ }^{3} \mathrm{H}-5$-hydroxytryptamine uptake by pulmonary endothelial cells. J Cell Biol 54:456

32. Sturgess J, Reid L 1972 An organ culture study of the effect of drugs on the secretory activity of human bronchial submucosal gland. Clin Sci 43:533

33. Webster HL, Barlow WK 1981 New approach to cystic fibrosis diagnosis by use of an improved sweat-induction/collection system and osmometry. Clin Chem 27:385

\title{
Utilization of Galactose in Cultured Brain Cells of Neonatal Mice
}

\author{
H. P. SCHWARZ, K. GENNARI, H. P. SIEGRIST, K. ZUPPINGER, T. SCHÄFER, U. WIESMANN, \\ AND N. HERSCHKOWITZ \\ Universitäts-Kinderklinik, Inselspital, Bern, Switzerland
}

\begin{abstract}
Metabolism of galactose was examined in dissociated brain cells from neonatal mice after 10-13 days in culture. Consumption of galactose at levels up to $26 \mathrm{mM}$ was much less than consumption of glucose at corresponding concentrations. Lactate was consumed from the media at all galactose levels, in contrast to experiments with glucose in which lactate was formed and released into the media. Generation of $\mathrm{CO}_{2}$ from $4 \mathrm{mM}$ glucose was 9-fold greater than from an equimolar level of galactose. Relatively low concentrations of glucose could reduce uptake of galactose, whereas galactose at levels up to $11.6 \mathrm{mM}$ failed to inhibit consumption of glucose or formation of lactate. In glucose-deficient states, galactose supplementation of the media led to a marked increase in sulfatide synthesis by oligodendrocytes in the culture with a maximum effect at $2.3 \mathrm{mM}$. Under these conditions, $\left[1-{ }^{14} \mathrm{C}\right]$ galactose was incorporated directly into the carbohydrate portion of sulfatide, although most of the label was found in phospholipids and in the nonlipid fraction of the cellular homogenate. These data suggest that galactose is poorly metabolized by brain cells, but does not exhibit toxic effects. (Pediatr Res 19: 52-57, 1985)
\end{abstract}

\section{Abbreviations}

DMEM, Dulbecco's modified Eagle's medium DIC, days in culture

Under normal conditions galactose is efficiently metabolized by the liver. Conversion to glucose occurs by Leloir's pathway which is particularly active in neonatal mammals and involves three main steps. First galactose is phosphorylated by galactokinase (EC 2.7.1.6) to galactose-1-phosphate. This latter compound

Received April 2, 1984; accepted July 24, 1984.

Correspondence Dr. H. P. Schwarz, Universitäts-Kinderklinik, Inselspital, CH3010 Bern, Switzerland.

This work was supported by the Schweizerischer Nationalfonds zur Förderung der wissenschaftlichen Forschung Grants 3.419-0.78 and 3.963-0.80. is converted with UDPglucose by galactose-1-phosphate uridylyl transferase (transferase, EC 2.7.7.12) to UDPgalactose and glucose-1-phosphate. Finally, UDPgalactose is interconverted to UDPglucose by the enzyme UDPglucose 4-epimerase (epimerase, EC 5.1.3.2). While the highest specific activity of these enzymes is found in liver, lower activities can be demonstrated in many tissues including the brain. Compared to liver, brain activity in the adult rat amounted to $27 \%$ for galactokinase (7), $15 \%$ for transferase (2), and $52 \%$ for epimerase (5). Shin-Buehring et al. (26) reported that activity for the first two enzymes in the brain of human fetuses stayed at a low and fairly constant level between the 7 th and 28 th wk of gestation. Despite the presence of these enzymes, the mammalian brain is not dependent on preformed galactose for the synthesis of galactolipids, gangliosides, mucopolysaccharides, and glycoproteins, because the necessary UDPgalactose can be formed from UDPglucose catalyzed by the epimerase.

Under pathologic clinical conditions, as in transferase deficiency or galactokinase-deficiency galactosemia (24), high galactose plasma level may reach the brain. Mental retardation is a hallmark of untreated transferase-deficiency galactosemia and also has been described in galactokinase-deficient individuals. However, the exact pathogenesis is still not known. Animal models, such as the galactose-toxic rat and the chicken, have permitted some insight into the mechanism of galactose brain toxicity, but, admittedly, these models differ markedly from the human disease states and some studies yielded contradictory findings (25). The toxic effects of galactose on the CNS include decreased brain development and decreased DNA content (11), Schwann cell changes and demyelination (21), reduced cerebral entry and content of glucose $(10,14,16)$, inhibition of glycolysis $(10,17)$, and energy metabolism (10).

The neonatal mouse brain cell culture established by Wiesmann et al. (31) is a model which allows the investigation of the effects of exogenous substrates at the cellular level without interference from the blood brain barrier. It has been used before to study utilization of glucose (33), ketones, and oleate (4). In the present work, experiments were performed when the cultures were at a developmental stage characterized by a high number of oligodendrocytes (3) and active synthesis of sulfatide, a major 